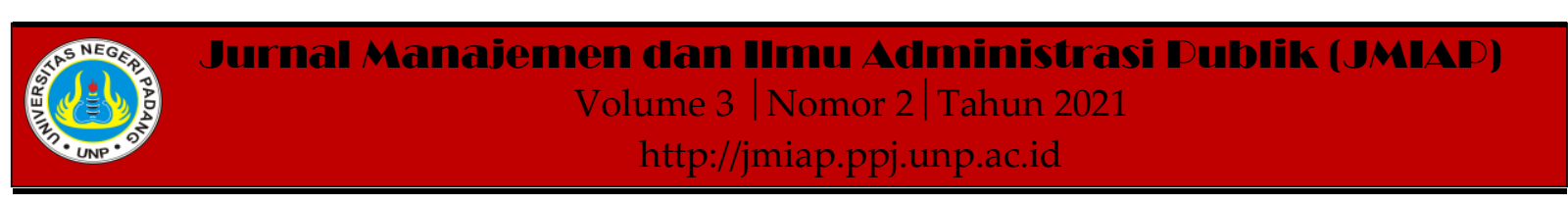

\title{
KINERJA DINAS KESEHATAN DALAM MENGAWASI KUALITAS AIR MINUM DI KOTA PADANG
}

\author{
Rila Amisa ${ }^{1(a)}$, Adil Mubarak ${ }^{2(b)}$ \\ ${ }^{1}$ Jurusan Ilmu Administrasi Negara, Universitas Negeri Padang \\ ${ }^{2}$ Jurusan Ilmu Administrasi Negara, Universitas Negeri Padang \\ a)rila.amisa62@gmail.com, ${ }^{b}$ adilmubarak@fis.unp.ac.id
}

\begin{abstract}
This research was done in Health Office Padang City, Which purpose to discover about to performance of the Padang City Health Office and the inhibiting factors in monitoring the quality of drinking water in the Padang City. The study applies a qualitative method using purposive sampling. Prosess aggregation data colth pass through observation, interview, and study documentation, while technique for validity the data testing that using resource triangulation with data analysis such as a data collection, data reduction, data presentation along with pulling conclusions. The results of the research conducted was explain performance of the Health Office in Supervising the Quality of Drinking Water in the City of Padang is not optimal, because there are still obstacles such as: Lack of supervision and attention from the Health Office to the community regarding the quality of drinking water that is fit for consumption, there are still limited funds, materials and tools for examining water samples, Besides that, there are also limited human resources so that all work in a certain section is held by only one person. It can be concluded that the performance of the Health Office has not been maximal in monitoring the quality of drinking water in Padang City.

Keywords : Performance, Supervision, Drinking Water Quality

Corresponding author. Email. rila.amisa62@gmail.com

How to cite this article. Amisa, R \& Mubarak. A. (2021). Kinerja Dinas Kesehatan dalam Mengawasi Kualitas Air Minum di Kota Padang. Jurnal Manajemen dan Ilmu Administrasi Publik (JMIAP) Jurusan Ilmu Administrasi Negara Fakultas Ilmu Sosial Universitas Negeri Padang, Volume 3 (2), Hal. 172179.

http://jmiap.ppj.unp.ac.id

Copyright@2021. Published by Labor Jurusan Ilmu Administrasi Negara FIS UNP, Padang
\end{abstract}




\section{PENDAHULUAN}

Kebutuhan terhadap air bersih bertambah banyak hal ini sebanding jumlah penduduk. Air sangat dibutuhkan dalam kehidupan terutama badan manusia diibaratkan udara dengan makanan karena air salah satu sarana pendukung dalam meningkatkan derajat kesehatan, disamping itu air juga wabah penularan penyakit. Oleh sebab itu air penting untuk manusia penting dalam membantu aktivitas terutama keperluan minum, tentunya air tersebut harus keadaan berkualitas buat dikonsumsi tidak mengganggu kebugaran.

Kualitas air bersih di Indonesia wajib memenuhi ketentuan aturan Menteri Kesehatan Republik Indonesia Nomor 492/MENKES/PER/IV/2010 tentang Persyaratan Kualitas Air Minum, seperti: air dikonsumsi menjalani tahap pengerjaan serta bisa spontan dikonsumsi yaitu: tiada berasa, beraroma, beragam, serta tiada menyimpan makhluk hidup kecil. Biarpun, air berawal dari bumi bisa di minum bagi manusia, namun air mengandung kuman (Saleh dkk,2013).

Kebutuhan masyarakat terhadap air minum, biar bersumber PDAM, sumur galian dan AMIU, tetapi masyarakat harus tetap memperhatikan kaulitas air minum yang akan diminum. Oleh sebab itu masyarakat hygiene air yang akan di minum. Jika penggunaan air minum bersumber PDAM ataupun sumur maka masyarakat harus memperhatikan hygiene air yang diminum, begitupun dengan AMIU.

Kebutuhan masyarakat dalam mengkonsumsi air minum demikian besar sehingga diperlukan pengawasan, pembinaan tekstur dan mutu air oleh dinas kesehatan supaya air dikonsumsi masyarakat tetap terjamin dan segar karena akan berdampak bagi kebugaran tubuh orang banyak serta segala aspek aktivitas.

Sejalan pertambahan kebutuhan dan kehendak masyarakat serta upaya buat mewujudkan keinginan negara. Pemerintahan menjalankan tiga fungsi hakiki yaitu pelayanan, pemberdayaan, dan pembangunan. Ketiga peranan ini bisa golongkan menjadi dua fungsi yaitu fungsi mendasar dan fungsi pendukung. Fungsi Primer merupakan fungsi yang selalu berjalan dan berkaitan positif dengan kondisi pihak yang diperintah. Fungsi sekunder adalah fungsi yang berkenaan negatif dengan kondisi ekonomi, politik, sosial masyarakat.( Mubarak, 2014).

Untuk Tata Laksana Pengawasan Kualitas Air Minum di atur dalam Peraturan Menteri Kesehatan Republik Indonesia No.736/MENKES/PER/VI/2010 termuat pada pasal 2 pengawasan kualitas air minum Pengawasan eksternal dijalankan oleh Dinas Kesehatan Kab/Kota dan pengawasan internal dilakukan oleh penyelenggara air minum. Untuk meningkatkan kesehatan yang optimal kepada seluruh masyarakat maka diperlukan Dinas Kesehatan merupakan moto pergerak utama yang akan mendorong masyarakat agar hidup sehat.

Akhir-akhir ini masih ada masyarakat banyak mengeluh terkait kualitas air minum, dimana air minum yang dikonsumsi masyarakat masih saja mengalami masalah seperti, air minum bersumber dari depot isi ulang seringkali memiliki rasa berbeda jika telah dikonsumsi selama 4-7 hari, dan mutu air minum bermula dari PDAM ada juga masih berasa airnya serta berbau, serta air yang berasal dari sumur bor tidak diketahui bagaimana kualitas airnya. Semua itu diakibatkan karena kurangnya perhatian dan pemeriksaan oleh Dinas Kesehatan Kota Padang terhadap mutu air minum yang dikonsumsi oleh masyarakat, sehingga masyarakat masih saja mengkonsumsi air yang kualitasnya tidak layak dikonsumsi. Masyarakat juga kurang menerima informasi terkait masalah kualitas air minum, karena Dinas Kesehatan kurang terbuka dalam mempublikasikan hasil dari pemeriksaan air yang telah diperiksa samplenya.

Tidak hanya PDAM, di Kota Padang terdapat sebesar 400 depot isi ulang air minum yang tiada bagus kualitas airnya. Depot yang tidak layak airnya untuk dikonsumsi itu, lokasinya tersebar di 11 
kecamatan. Dinas Kesehatan sudah melayangkan surat ke pemilik depot melalui puskesmas agar segera melakukan pemeriksaan ke labor kesehatan di Gunung Pangilun (Harian pagi Posmetro Padang, 2019).

Dalam melakukan pemeriksaan sampel air Dinas Kesehatan terkendala dengan jumlah dana. Lebih lanjut dijelaskan oleh Ibu $\mathrm{R}$ terkait target pemeriksaan sample air minum yaitu:

...."Dinas Kesehatan Kota Padang melakukan pengawasan eksternal satu kali setahun. Dalam tahun 2019, untuk pengambilan sample air dari PDAM dan sumur bor, Dinas Kesehatan yang dibantu oleh pegawai puskesmas setempat mengambil sample kerumah warga yang memakai PDAM dan sumur bor, untuk depot air minum dinas kesehatan langsung ke lokasi depotdepot yang beredar. Pengambilan sample tersebut tidak menyeluruh, karena dibatasi dana, jadi hanya beberapa sample saja yang diambil"'(Wawancara 2020).

Berdasarkan hasil wawancara di atas dapat penulis gambarkan bahwa Kinerja Dinas Kesehatan dalam Mengawasi Kualitas Air Minum di Kota Padang belum maksimal hal ini sebabkan karena adanya keterbatasan dana dalam pemeriksaan sampel air, serta kekurangan tenaga pengawas untuk pemeriksaan kualitas air minum baik yang ada di Dinas Kesehatan maupun Puskesmas se Kota Padang. Berikut tabel jumlah Jumlah Pegawai Pengawas Bidang Sanitasi Puskesmas SeKota Padang:
Tabel Jumlah Pegawai Pengawas Bidang Sanitasi Puskesmas Se-Kota Padang

\begin{tabular}{|c|c|c|c|c|}
\hline \multirow[b]{2}{*}{ No } & \multirow[b]{2}{*}{ Puskesmas } & \multicolumn{2}{|c|}{ Jumlah } & \multirow{2}{*}{ Total } \\
\hline & & Pria & Wanita & \\
\hline 1. & Puskesmas Bungus & 1 & 0 & 1 \\
\hline 2. & Puskesmas Lbk. Kilangan & 1 & 0 & 1 \\
\hline 3. & Puskesmas Lbk.Begalung & 0 & 1 & 1 \\
\hline 4. & Puskesmas Pengambiran & 1 & 0 & 1 \\
\hline 5. & Puskesmas Seberang Padang & 0 & 1 & 1 \\
\hline 6. & Puskesmas Pemancungan & 0 & 2 & 2 \\
\hline 7. & Puskesmas Rawang Barat & 0 & 2 & 2 \\
\hline 8. & Puskesmas Andalas & 0 & 2 & 2 \\
\hline 9. & Puskesmas Padang Pasir & 0 & 2 & 2 \\
\hline 10. & Puskesmas Ulak Karang & 0 & 1 & 1 \\
\hline 11. & Puskesmas Air Tawar & 0 & 1 & 1 \\
\hline 12. & Puskesmas Alai & 0 & 2 & 2 \\
\hline 13. & Puskesmas Nanggalo & 0 & 3 & 3 \\
\hline 14. & Puskesmas Lapai & 0 & 2 & 2 \\
\hline 15. & Puskesmas Belimbing & 0 & 2 & 2 \\
\hline 16. & Puskesmas Kuranji & 0 & 2 & 2 \\
\hline 17. & Puskesmas Ambacang Kri & 0 & 2 & 2 \\
\hline 18. & Puskesmas Pauh & 1 & 1 & 2 \\
\hline 19. & Puskesmas Air Dingin & 1 & 1 & 2 \\
\hline 20. & Puskesmas Lb. Buaya & 0 & 1 & 1 \\
\hline 21. & Puskesmas Ikur Koto & 0 & 1 & 1 \\
\hline 22. & Puskesmas Anak Air & 1 & 1 & 2 \\
\hline 23. & Puskesmas Dadok Tg.Hitam & 0 & 2 & 2 \\
\hline & Jumlah & 6 & 32 & 38 \\
\hline
\end{tabular}

(Sumber: Http://dinaskesehatan.kotapadang.go.id)

Dari penjelasan tabel diatas bisa diketahui maka terdapat setiap puskesmas memiliki pegawai yang sedikit, sehingga dalam pemeriksaan sampel air hanya dilakukan 1 orang ataupun 2 orang petugas, dan hal tersebut tiada bekerja dengan maksimal. Oleh sebab itu perlu adanya penambahan pegawai dalam pemeriksaan sampel air tersebut.

Berdasarkan pengamatan penulis Kinerja Dinas Kesehatan belum berjalan maksimal terlihat dari penjelasan di atas, maka perlu di tingkatkan dan diperbaiki lagi. Sehingga dari permasalahan di atas peneliti terdorong melaksanakan penelitian dengan topik " Kinerja Dinas Kesehatan dalam Mengawasi Kualitas Air Minum di Kota Padang”.

\section{TINJAUAN PUSTAKA \\ Konsep Kinerja}

Pada setiap organisasi kinerja merupakan salah satu faktor pendukung dan penunjang untuk mencapai bagi keberhasilan organisasi. Oleh sebab itu semua organisasi selalu berusaha untuk meningkatkan kinerja pegawainya agar tujuan dan keinginan organisasi 
sebelumnya dapat tercapai. Tujuan pencapaian kinerja pegawai sangatlah diperlukan, sebab dengan adanya pencapaian kineja tersebut dapat mengetahui seberapa jauh kemampuan dari diri seorang pegawai untuk melaksanakan dan menyelesaikan tugas yang diberikan kepadanya.

Hasibuan dalam Yani (2012:117) mengemukakan bahwa kinerja merupakan Prestasi kerja yang dihasilkan seseorang dinilai dari keahlian, pengetahuan dan pengalaman serta ketepatan waktu terhadap tugas yang diamanahkan kepadanya.

Prawirosentono dalam Sinambela (2012:5) mengartikan bahwa kinerja merupakan prestasi yang diperoleh oleh seseorang di organisasi untuk menggapai tujuan secara resmi, berpedomaan pada hukum serta memiliki moral dan etika.

Sedangkan Moeheriono ( 2011:162) mendefinisikan kinerja sebagai penilaian atas hasil kerja. Penilaian terhadap kinerja acuan untuk mengukur pencapaian tujuan organisasi dengan jadwal tertentu.

Dari kumpulan pengertian kinerja di atas, di ambil kesimpulan kinerja organisasi merupakan level perolehan terhadap implementasi kegiatan yang sudah disusun, di rancang agar target, serta maksud organisasi dalam periode tertentu dapat terlaksana.

\section{Konsep Pengawasan}

Sebuah rencana tidak akan berhasil tanpa suatu pengawasan. Pengawasan sangat penting dilakukan oleh suatu organisasi untuk menjamin bahwa semua kegiatan operasional yang dilakukan oleh organisasi dapat berjalan dengan baik. Mengingat bahwa semua rencana yang telah ditetapkan organisasi tidak selalu sesuai dengan apa yang dirancang karena individu di dalam organisasi bisa saja melakukan kesalahan, oleh karena itu pengawasan dalam suatu organisasi sangat penting dilakukan.

Menurut Irham (2016:96) secara menyeluruh arti pengawasan ialah proses dalam suatu organisasi menghasilkan hasil kerja berdaya guna dan ekonomis untuk menjunjung tercapainya tujuan dan target organisasi. Winardi (2000:379) mengemukakan pengawasan ialah kegiatan demi mendapatkan, memperbaiki kesalahan bermanfaat untuk aktivitas-aktivitas yang direncanakan.

Sementara Erick (2018:73) mengartikan pengawasan ialah suatu cara untuk menentukan tolak ukur dari kinerja serta melakukan kegiatan yang bisa membantu pencapaian tujuan yang diinginkan.

Menurut Torang (2013:97) berpendapat mengenai pengawasan adalah suatu tindakan yang dibuat dengan maksud agar mengetahui keadaan organisasi maupun pelaksanaan programnya. Jika ingin pelaksanaan pengawasan tersebut ditemukan kekeliruan, harus segera dilakukan perbaikan supaya tujuan organisasi dapat berjalan dengan baik dan efisien. Sedangkan George R. Terry dalam Efendi (2014:206) mengartikan pengawasan merupakan hal yang memastikan apa yang dicapai, mengevaluasinya, dan menerapkan tindakan.

Dari banyak pengertian pengawasan diatas dapat disimpulkan pengawasan ialah suatu proses untuk menenukan, mengoreksi, menilai pelaksanaan kegiatan yang dilakukan di dalam organisasi dapat sesuai dengan rencana semula.

\section{Konsep Kualitas Air Minum}

Persyaratan kualitas air minum telah di atur dalam peraturan Permenkes Nomor 492/MENKES/PER/IV/2020. Air minum merupakan air yang di proses melalui tahap dan tanpa pengolahan yang sudah melengkapi ketentuan kesehatan serta bisa dikonsumsi langsung. Air minum terjamin akan kesehatan bila memenuhi persyaratan fisika, mikrobiologis, kimiawi, dan radioaktif yang disusun dalam standar utama dan standar pendukung.

Untuk memperhatikan mutu air minum yang dikonsumsi masyarakat dilakukan pengawasan eksternal pengawasan yang laksanakan oleh Dinas Kesehatan kabupaten/Kota. Pengawasan internal 
merupakan pengawasan yang dijalankan oleh penyelenggara air minum untuk menjamin nilai air minum yang dihasilkan.

Metode pengadaan air bersih yang baik menurut Joko dalam Yani (2015), harus memiliki tujuan sebagai berikut:

1) Memfasilitasi kualitas air agar terjamin dan kondusif untuk penggunanya.

2) Menyediakan air yang jumlahnya mencukupi.

3) Menyiapkan air secara mudah dan murah sehingga bisa membantu kesehatan individu dan masyarakat banyak.

\section{METODE PENELITIAN}

Metode penelitian ini menerapkan kualitatif dengan menggunakan purposive sampling. Adapun lokasi penelitian berada di Dinas Kesehatan Kota Padang Proses pengumpulan data melalui observasi, wawancara, dan studi dokumentasi. Untuk cara pengujian keabsahan datanya dengan analisis triangulasi sumber yaitu: reduksi data, penyajian data serta penarikan kesimpulan.

\section{HASIL DAN PEMBAHASAN}

Berdasarkan temuan hasil penelitian yang sudah dikemukakan sebelumnya mengenai kinerja dinas kesehatan dalam mengawasi kualitas air minum di Kota Padang, maka bagian ini dijelaskan 2 hal sesuai dengan rumusan masalah yaitu:

\section{Kinerja Dinas Kesehatan dalam Mengawasi Kualitas Air Minum di Kota Padang}

Dalam mengetahui Kinerja Dinas Kesehatan dalam Mengawasi Kualitas Air minum di Kota Padang maka peneliti menggunakan tiga indikator kinerja menurut Uha (2013:243), yaitu :

\section{1) Indikator Masukan}

a. Kebijakan. Segala sesuatu tindakan yang dilakukan oleh pemerintah yang didasarkan untuk kepentingan umum masyarakat pasti ada kebijakan yang dijadikan sebagai acuan. Begitu juga dengan pemeriksaan kualitas air minum yang laksanakan oleh pihak Dinas Kesehatan Kota Padang kepada masyarakat dan produsen air minum. Dinas Kesehatan Kota Padang sudah bepedoman pada kebijakan sebagaimana mestinya yang telah diatur dalam Peraturan Menteri Kesehatan Nomor 492/MENKES/ PER/ IV/ 2010 serta Nomor 736/MENKES/PER/IV/ 2010 dijelaskan kriteria air minum yang siap dikonsumsi serta teknis pengawasan jalankan secara dalam maupun luar

b. Sumber Daya Manusia

Melaksanakan pengawasan pada mutu air minum tentunya Dinas Kesehatan Kota Padang butuh sumber daya manusia yang kompeten dalam mengawasi kualitas air minum. Namun, hal tersebut masih belum tercapai disebabkan baik jumlah tenaga ahli maupun yang kompeten untuk mengawasi kualitas air minum masih kurang dikarenakan jangkauan wilayah kerjanya tidak sebanding dengan keahlian dan jumlah tenaga manusia yang dikerahkan.

c. Informasi

Kelancaran program pengawasan juga bergantung pada kinerja petugas menghimpun informasi di lapangan. Baik itu laporan hasil pengawasan maupun argumen masyarakat. Beragam langkah sudah dilakukan Dinas Kesehatan untuk menjaga tekstur air minum di Kota Padang belum berjalan dengan maksimal, hal tersebut dikarenakan laboratorium Dinas Kesehatan Kota Padang belum terakreditasi, sehingga tidak bisa mempublikasi langsung kepada media cetak atau elektronik, namun hal tersebut menjadi tidak sebanding dalam Peraturan Menteri Kesehatan Republik Indonesia Nomor 
736/MENKES/PER/VI/2010

terdapat pada Pasal 27 yang berbunyi : " Menjelaskan bahwa pemerintah harus mempublikasikan hasil pengawasan minimal satu kali setahun melalui media cetak dan elektronik.

\section{2) Indikator Proses}

Dinas Kesehatan Kota Padang melakukan pengawasan setiap satu kali setahun yang dibantu oleh UPTD Puskesmas yang ada di Kota Padang.Untuk menjalankan tugas dalam mengawasi kualitas air minum, ada bentuk pengawasan yaitu pengawasan dekat dan pengawasan jauh.

Ada dua macam pengawasan yang di lakukan oleh Dinas Kesehatan Kota Padang dalam pemeriksaan sampel air yaitu:

a. Pengawasan Dekat adalah pengawasan ini dilakukan di tempat kegiatan yang bersangkutan, yang dilakukan dengan cara Dinas Kesehatan yang dibantu oleh UPTD Puskesmas melakukan pengambilan sample langsung ke lapangan sesuai dengan Standar Operasional Prosedure;

b. Pengawasan Jauh. Pengawasan ini dilakukan oleh pihak penyelenggara air minum, contohnya Pengisian Air Minum Isi Ulang seperti Depot. Pemilik depot wajib mengecek sample airnya ke laboratorium terakreditasi dan memberikan hasilnya kepada Dinas Kesehatan Kota Padang jika hasil samplenya sesuai dengan persyaratan kualitas air minum, maka Dinas Kesehatan akan memberikan sticker Rekomendasi untuk punya depot air minum.

Dalam melakukan pengawasan untuk pengecekkan sampel air Dinas Kesehatan Kota Padang memiliki target setiap tahunnya. Dinas Kesehatan Kota Padang memberikan target kepada masing-masing puskesmas karena jika seluruh sumber air diperiksa maka tidak cukup dana, alat, bahan dan petugas. Karena keterbatasan hal tersebut maka di berikan target pada masing-masing puskesmas.

\section{3) Indikator Keluaran}

Sesuatu yang diinginkan dari aktivitas dapat berwujud fisik dan non fisik. Dalam meningkatkan pengawasan terhadap kadar air minum isi ulang yang berada diwilayah Kota Padang, Dinas Kesehatan memiliki target yang ingin dicapai yaitu terlindungnya masyarakat dari dampak buruk akibat penggunaan air yang tidak layak dikonsumsi. Harapan dinas kesehatan Kota Padang adalah 100\% masyarakat akses air minum yang layak.

Dinas kesehatan memiliki target $100 \%$ masyarakat akses air minum yang layak, tetapi harapan tersebut belum tercapai sepenuhnya karena masih ada beberapa penduduk yang masih mengkonsumsi air sungai serta masih ada pengusaha depot air minum yang tidak melakukan pengawasan internal dan tidak peduli dengan kualitas air depotnya, masyarakat juga masih kurang kesadaran terhadap kesehatannyadan tidak mematuhi arahan dan aturan dari rekomendasi Dinas Kesehatan Kota Padang tentang air minum yang layak untuk dikonsumsi sebagai kebutuhan sehari-hari.

\section{Faktor Penghambat Dinas Kesehatan dalam Mengawasi Kualitas Air Minum di Kota Padang}

Pelaksanaan terhadap suatu kegiatan tidak luput dari berbagai kendala maupun faktor yang muncul baik secara internal maupun eksternal. Dalam penelitian ini terdapat dua faktor yang menjadi penghambat yaitu:

\section{1) Faktor Internal}

Dari hasil temuan penelitian faktor internal yang menjadi faktor penghambat Kinerja Dinas Kesehatan dalam mengawasi kualitas air minum di Kota Padang adalah:

a. Penyuluhan

Dalam melakukan penyuluhan mutu air minum yang dilaksanakan Dinas Kesehatan Kota padang belum tercapai terkait hal 
pengawasan. Hal tersebut dikarenakan belum meratanya kegiatan penyuluhan yang dilakukan oleh setiap puskesmas mengenai kualitas air minum yang seharusnya dikonsumsi, hal ini mengakibatkan masih terdapat dari masyarakat yang tidak mengetahui dampak bahaya akan air minum jika tidak layak dikonsumsi. Kegiatan khusus penyuluhan yang dilakukan Dinas Kesehatan Kota Padang Penyuluhan ini tidak berlangsung dengan optimal karena dana untuk melakukan itu tidak ada, ketika ada kegiatan ke sekolah atau mengumpulkan masyarakat maka Dinas Kesehatan hanya memberikan sedikit informasi saja mengenai kualitas air minum layak dikonsumsi.

b. Sumber Daya Pendukung

Anggaran yang dimiliki Dinas Kesehatan Kota Padang untuk pembiayaan pengerjaan pengawasan kualitas air minum berasal dari dana APBN atau APBD. Untuk pemeriksaan mutu air minum Dinas Kesehatan Kota Padang kekurangan bahan dan alat seperti kapas dan pipet karena kekurangan alat dan bahan maka dinas kesehatan melakukan sterlisasi alat $2 \mathrm{x}$ dalam pemeriksaan sample air sehingga hal tersebut menghambat kinerja Dinas Kesehatan Kota Padang.

\section{2) Faktor Eksternal}

Dari hasil temuan faktor eksternal dalam penelitian ini yaitu:

a. Penyelenggara Air Minum

Penyelenggaran air minum masih saja mengabaikan kewajibannya untuk melaksanakan pemeriksaan internal seperti depot air minum isi ulang sehingga hyginies airnya belum terjamin padahal sudah diperingati oleh pihak dinas kesehatan tetapi pengusaha depot masih tidak memiliki kesadaran untuk memeriksakan sampel air.

b. Masyarakat

Karena adanya penolakan dari masyarakat ketika petugas ingin melakukan pemeriksaan sampel air rumah tangga, hal tersebut disebabkan karena kurangnya pengetahuan dan kurangnya mendapatkan informasi sehingga masyarakat masih saja tidak peduli dengan kualitas air minum yang layak dikonsumsi.

\section{PENUTUP}

Berdasarkan dari hasil penelitian yang dilakukan penulis tentang Kinerja Dinas Kesehatan dalam mengawasi kualitas air minum di Kota Padang dijelaskan belum maksimal, karena ada faktor penghambat dalam mewujudkan kinerja Dinas Kesehatan agar lebih baik untuk mengawasi mutu air minum yaitu:

Pertama faktor internal berupa tidak adanya kegiatan penyuluhan khusus mengenai kualitas air minum, sehingga hanya dilakukan di sekolah-sekolah ataupun disaat ada kegiatan mengumpulkan warga, hal ini disebabkan karena tidak ada dana khusus untuk itu. Selain itu juga ada sumber daya pendukung yang terbatas seperti keterbatasan bahan maupun alat untuk melakukan pemeriksaan sampel air.

Kedua faktor eksternal yang dilakukan oleh penyelenggara air minum ( depot), karena adanya sifat kurang kesadaran dalam memeriksa kualitas air minum, sehingga jika ada dari depot yang memiliki sampel air positif maka akan diberi surat peringatan. Selain itu juga ada faktor penghambat dari masyarakat, karena sikap penolakan dari masyarakat ketika petugas ingin melakukan pemeriksaan atau pengambilan sampel air rumah tangga, hal tersebut disebabkan karena kurangnya pengetahuan atau informasi tentang kadar air minum yang layak untuk dikonsumsi.

Dari hasil penelitian saran yang dapat diajukan agar Kinerja Dinas Kesehatan dalam Mengawasi Kualitas Air Minum di 
Kota Padang meningkat maka penulis menyarankan yaitu : 1) Pemko Padang diharapkan memiliki anggaran yang cukup agar Dinas Kesehatan Kota Padang dapat melakukan kegiatan pemeriksaan sampel air dan pengawsan air minum di Kota Padang; 2) Menambah tenaga sumber daya manusia sesuai dengan bidangnya, baik kualitas serta kuantitasnya. Sebab, akan berbahaya terhadap kesehatan masyarakat dalam mengkonsumsi sumber air minum yang terkontaminasi; 3) Menambah Sumber Daya Pendukung atau sarana dan prasarana (bahan dan alat) seperti kapas dan pipet untuk strelisasi air.

\section{DAFTAR KEPUSTAKAAN}

Erick, T. P. B. (2018). Pengaruh Pengawasan, Akuntabilitas dan Transparansi Keuangan Terhadap Kineja pegawai. Jurnal Riset Akuntansi Going Concern, 13, 72-79.

Irham, F. (2016). Perilaku Organisasi " Teori, Aplikasi dan Kasus.

Moeheriono. (2011). Perencanaan, Aplikasi dan Pengembangan Iindikator Kinerja Utama.

Mubarak, A. (2014). Peran ORMAS Dalam Menjalankan Fungsi Pemerintah Bidang Pemberdayaan. repository.ut.ac.id.

Saleh. R. (2013). Efektivitas Unit Pengolahan Air di Depot Air Minum Isi Ulang (DAMIU) dalam Menurunkan Kadar Logam dan Mikroba di Kota Pekalongan. Jurnal Kesehatan Lingkungan Indonesia, Vol 1.

Sinambela, L. (2012). Kinerja Pegawai, Teori Pengukuran dan Implikasi.

Syamsir, T. (2013). Organisasi dan Manajemen.

Usman, E. (2014). Asas Manajemen.

Winardi. (2000). Asas-asas Manajemen.

Yani, M. (2012). Manajemen Sumber Daya
Manusia.

$\begin{array}{lr}\text { Permenkes } & \text { Nomor } \\ \text { 492/Menkes/PER/IV/2010 } & \text { Tentang } \\ \text { Persyaratan Kualitas Air Minum. (n.d.) }\end{array}$

Permenkes Nomor

736/Menkes/Per/IV/2010 tentang Tata Laksana Pengawasan Kualitas Air Minum. (n.d.). 